\title{
Groundwater Quality Assessment for Drinking Purpose Based on Physicochemical Analysis in Teluk Nilap Area, Rokan Hilir, Riau, Indonesia.
}

\author{
Arief Yandra Putra ${ }^{1, *}$, Fitri Mairizki ${ }^{2}$ \\ ${ }^{1}$ Department of Chemistry Education, Faculty of Teacher Training and Education, Universitas Islam Riau, Pekanbaru, Indonesia \\ ${ }^{2}$ Department of Geological Engineering, Faculty of Engineering, Univeristas Islam Riau, Pekanbaru, Indonesia.
}

* Corresponding author : ariefyandra0811@edu.uir.ac.id

Tel.:+62-813-7456-7116

Received: August 1, 2020; Accepted: August 27, 2020.

DOI: 10.25299 /jgeet.2020.5.3.5488

\begin{abstract}
Groundwater is water resource that widely used for domestic purposes, including for drinking. However, the industrial and population growth causes the quality and quantity of groundwater to decline. In this case, the quality of drinking water in Indonesia must meet the requirements according to Health Minister Regulation No.492/MENKES/PER/IV/2010. This study aims are to determine the quality of groundwater in the research area based on physicochemical parameters and its evaluation for drinking water. Groundwater samples were taken from dug wells in Teluk Nilap area, Rokan Hilir, Riau. Groundwater samples have temperature average $30^{\circ} \mathrm{C}$, TDS average $312,5 \mathrm{mg} / \mathrm{L}$ and $\mathrm{pH}$ average 5,6. Groundwater contain sulfate and nitrate with average value 48,8 mg/L and 11,86 mg/L, respectively. Groundwater water also have iron and lead metal above the permitted standard with average value 2,57 mg/L and 0,022 $\mathrm{mg} / \mathrm{L}$. Groundwater in the study is not recommended as drinking water.
\end{abstract}

Keywords: Groundwater, physical, chemical, drinking water

\section{Introduction}

Groundwater is one of the basic necessities for humans. Groundwater is a natural resource that needs to be preserved and it has various functions to support human life. Groundwater is the main water resource that used for drinking water by community. Groundwater has many advantages compared to the other water resource such as: groundwater quality is better than surface water quality, groundwater quality does not depend on the season, there is a large amount of groundwater reserves and easy to obtain. However, population and industrial growth have caused the quality and quantity of groundwater to decline. One of the contributing factor is the presence of pollutants from garbage disposal area (Satrio, et al., 2017), industrial activities (Naslilmuna, et al., 2018) and domestic waste, both liquid and solid waste (Sasongko, 2014).

The use of groundwater for domestic purposes including for drinking must meet the requirements determined by national and international regulations. In this case, the quality of drinking water in Indonesia must meet the requirements for physical, chemical, and biological parameters according to the Health Minister Regulation No. 492/MENKES/PER/IV/2010. Drinking water must be free from harmful bacteria and chemical impurities. Drinking water also must be clean and clear, odorless and colorless, have no suspended matter or turbidity (Risky, D.P., et al., 2017). It is necessary to monitor the quality of groundwater intensively and continuously to ensure that the groundwater used is suitable and safe for consumption. For this reason, a lot of research has been carried out on monitoring groundwater quality which used as a source of drinking water in various countries (Siringoringo, et al., 2019) ; (Ibrahim, M.N., 2019) ; (Khan, A., Khan, M.A., 2018) ; (Lalitha, B.V., 2016) ; (Annapoorna, H., Janardhana, M.R., 2015). Therefore, the aims of this research are to determine groundwater quality in study area based on physicochemical parameters and groundwater assessments for drinking purpose.

\section{Study Area}

Teluk Nilap is one the villages located in Kubu Babussalam Subdistrict, Rokan Hilir, Riau. Topographically, Teluk Nilap is low land with altitude about 6-10 m from sea level. The people of Teluk Nilap use groundwater for domestic purpose. However, at this time, the people in the study area feel a change in environmental condition including the decrease of groundwater quality. The groundwater looks brownish, oily, sticky to the skin and does not foam when given soap. Based on the regional map, stratigraphy of research area composed by young superficial deposits $(\mathrm{Qh})$ and older superficial deposits (Qp) (Fig.1). The rocks in young superficial deposits are clays, silts and clean gravels, vegetation rafts and peat swamps. On the other hand, the older superficial deposits consist of clays, silts and clayey gravels, vegetation rafts. 


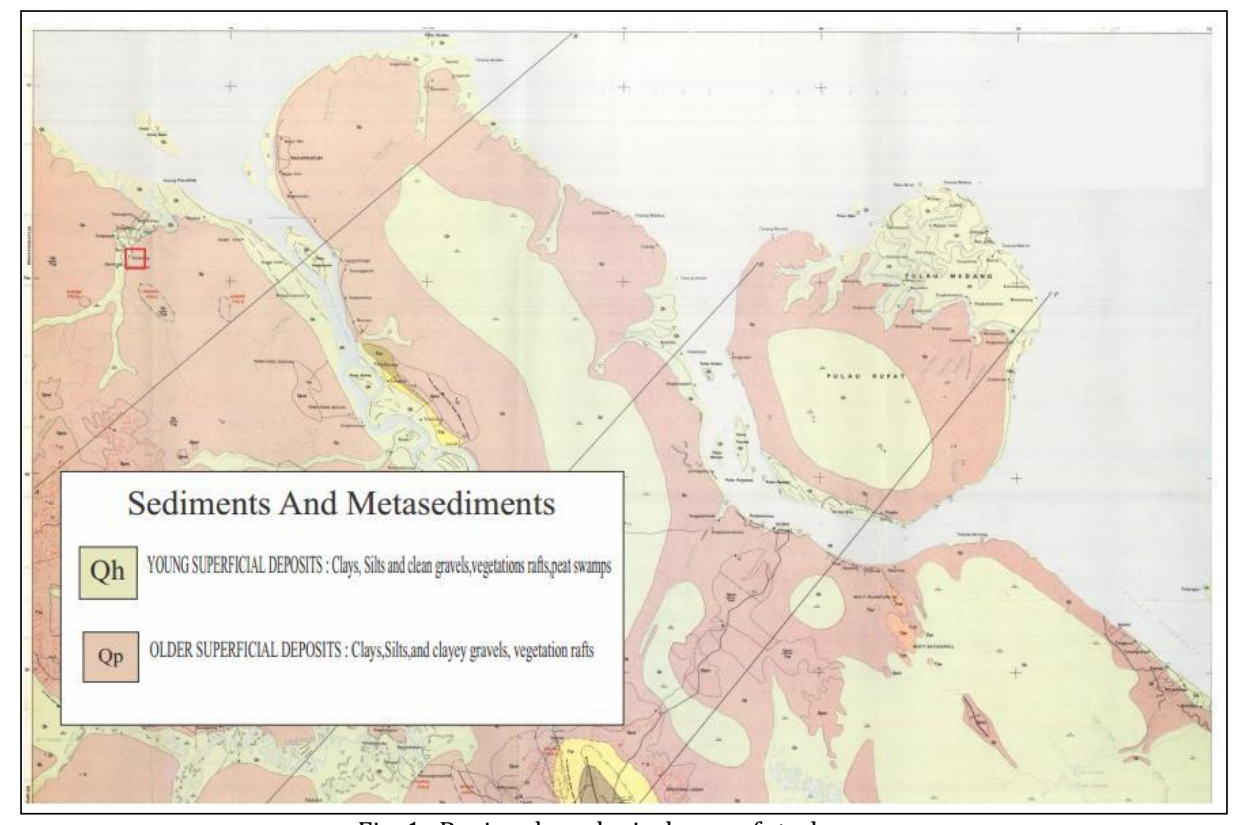

Fig. 1. Regional geological map of study area

\section{Methodology}

The groundwater samples were taken from dug wells in Teluk Nilap area with random sampling method. All samples were examined for physicochemical analysis in the Industrial Research and Standardization Laboratory, Padang. The temperature, TDS and $\mathrm{pH}$ of collected samples were determined by using thermometer, TDS meter and $\mathrm{pH}$ meter, respectively. Sulfate and nitrate concentrations were determined by using Spectrophotometer. Iron and lead concentrations were determined by using Atomic Absorption Spectrophotometer. The quantitative data on physicochemical parameters obtained then compared with the drinking water quality standards based on Health Minister Regulation No.492/MENKES/PER/ IV/2010.

\section{Result and Discussion}

\subsection{Temperature}

In general, temperature condition of groundwater is normal value, in range $27-31^{\circ} \mathrm{C}$ and average $30^{\circ} \mathrm{C}$ which meet the drinking water quality standard. The temperature standard permitted by Health Minister Regulation is air temperature $\pm 3^{\circ} \mathrm{C}$. The research area is belongs to the tropical climate. Water temperature can be affected by season, latitude, altitude, cloud cover, flow and depth of water. The large amounts of dissolved chemicals (phenol, sulfur) and decomposition of organic matter by microorganism can also cause groundwater temperature value will be above standard limit (Mairizki, F., Cahyaningsih, C., 2016).

\subsection{Total Dissolved Solid (TDS)}

TDS values of groundwater also show the normal value with average $312,5 \mathrm{mg} / \mathrm{L}$ in range $101-809 \mathrm{mg} / \mathrm{L}$. TDS standard permitted by Health Minister Regulation is $500 \mathrm{mg} / \mathrm{L}$. Only 3 groundwater (20\%) that have TDS value over the drinking water quality standard (Fig.2). All groundwater were classified as fresh water (TDS 0-2000 mg/L) (Putra, D.B.E., et al., 2019).

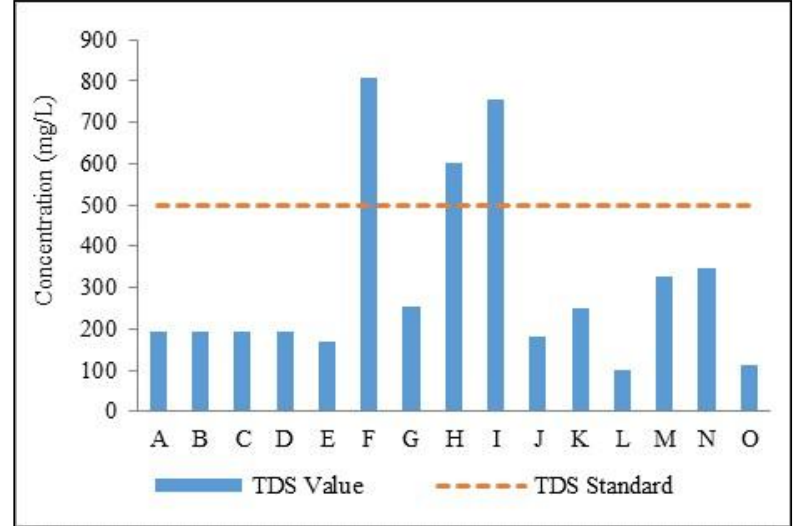

Fig 2. Total dissolved solid value of groundwater

TDS consist of soluble organic or soluble inorganic compounds, minerals and dissolved gases. Salts that dissolve in groundwater which contain magnesium, sodium, sulfate or chloride ions also increase the amount of dissolved solids in groundwater. The presence of TDS such as sodium sulfate and magnesium sulfate can cause a change in groundwater taste. In addition, the high concentration of total dissolved solids affect the clarity, groundwater color and hardness (Firdaus, et al.,2017).

\section{$4.3 \mathrm{pH}$}

$\mathrm{pH}$ condition of groundwater in range 2,8-6,6 and average 5,6. $\mathrm{pH}$ standard permitted by Health Minister Regulation is 6,5-8,5. Almost all groundwater are acidic and do not meet drinking water quality standard (Fig.3). This is due to geological factors such as soil conditions. The study area is dominated by peat.

$\mathrm{pH}$ value will determine the corrosion properties. The properties of corrosion will be higher at low $\mathrm{pH}$. Water with low $\mathrm{pH}$ also will easily dissolve the Fe metal that form ferrous and ferric ions which can cause the water become colored, smelly and have a taste (Putra, A.Y., Mairizki, F., 2019). 


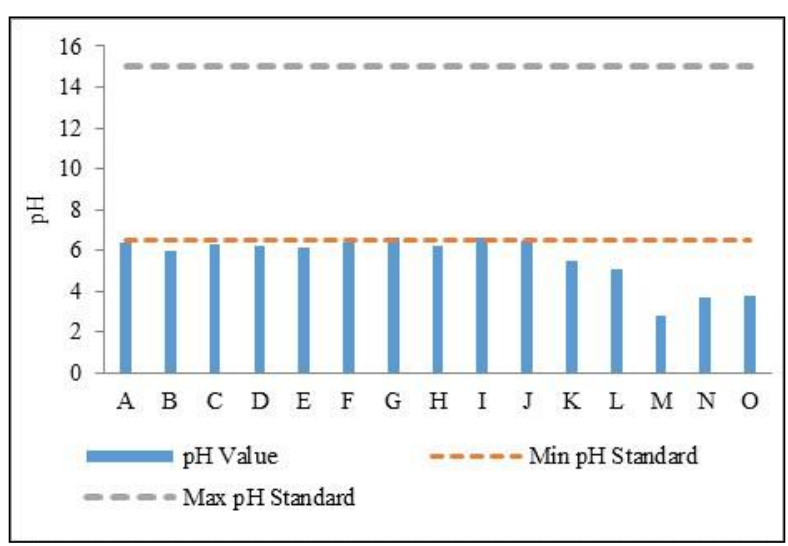

Fig 3. pH value of groundwater

\subsection{Sulfate}

Sulfate condition of groundwater show the normal value with average $48,8 \mathrm{mg} / \mathrm{L}$ in range $11,76-118,73 \mathrm{mg} / \mathrm{L}$. Sulfate standard permitted by Health Minister Regulation is $250 \mathrm{mg} / \mathrm{L}$. All groundwater meet the drinking water quality standard (Fig.4).

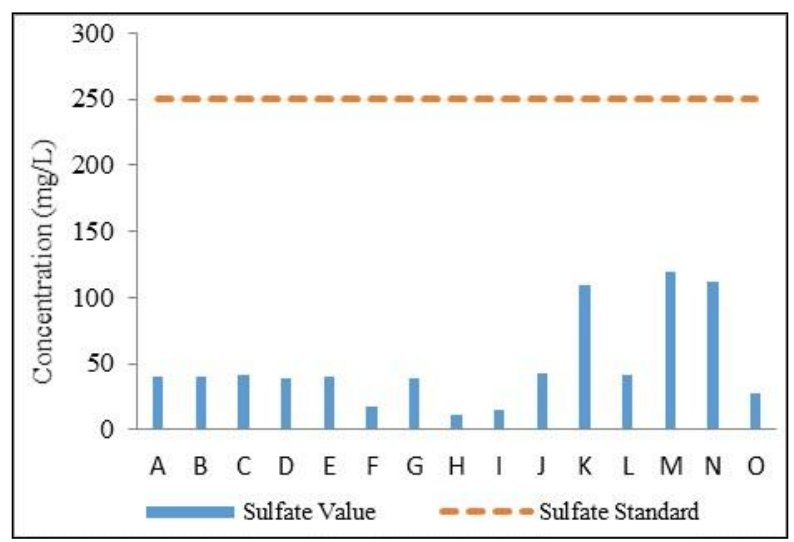

Fig 4. Sulfate value of groundwater

The presence of sulfate in groundwater can be influenced by the type of rock that the groundwater passes through. Sulfates are found in sedimentary and igneous rocks as sulfides metal. Sulfate is found in igneous rocks as feldspatoid, and also found in many evaporite sedimentary rocks as gypsum, anhydrite and barite. In weathering, sulfur is oxidized to produce sulfate ions which are carried by groundwater (Mutianto, H., 2010).

\subsection{Nitrate}

Nitrate condition of groundwater also show the normal value in range $1,828-20,852 \mathrm{mg} / \mathrm{L}$ and average 11,86 $\mathrm{mg} / \mathrm{L}$. Nitrate standard permitted by Health Minister Regulation is $50 \mathrm{mg} / \mathrm{L}$. All groundwater have nitrate value below the drinking water quality standard (Fig.5).

The presence of nitrate in high amounts at groundwater indicated the decomposition of organic compounds through biological processes with very low dissolved oxygen. Nitrate content in groundwater can also come from agricultural materials such as nitrate fertilizers. Nitrate residue will be carried by rainwater into the soil which increasing nitrate values in groundwater (Sudaryanto, Suherman, D., 2008).

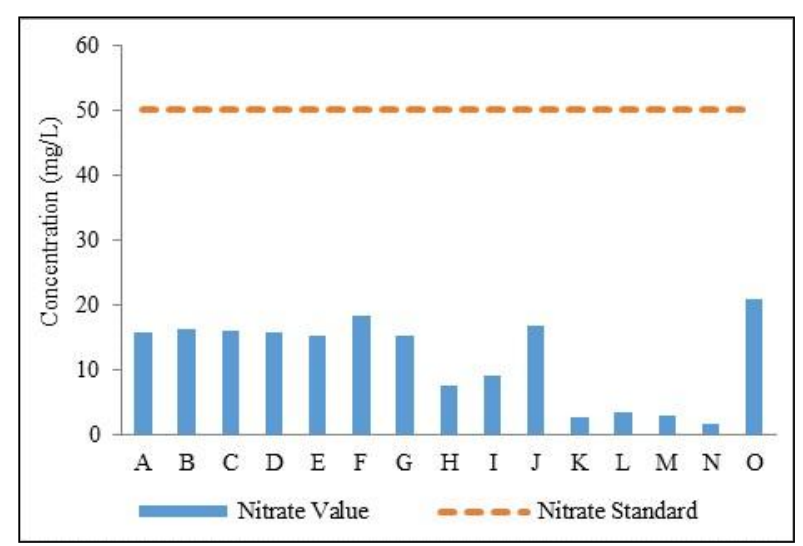

Fig 5. Nitrate value of groundwater

\subsection{Iron}

Most groundwater have high concentration of $\mathrm{Fe}$ metal with average 2,57 in range $0,18-6,87 \mathrm{mg} / \mathrm{L}$. Fe standard permitted by Health Minister Regulation is 0,3 $\mathrm{mg} / \mathrm{L}$. Only 1 groundwater $(6,67 \%)$ has Fe value below the drinking water quality standard while the others have high Fe metal content above the quality standard (Fig.6).

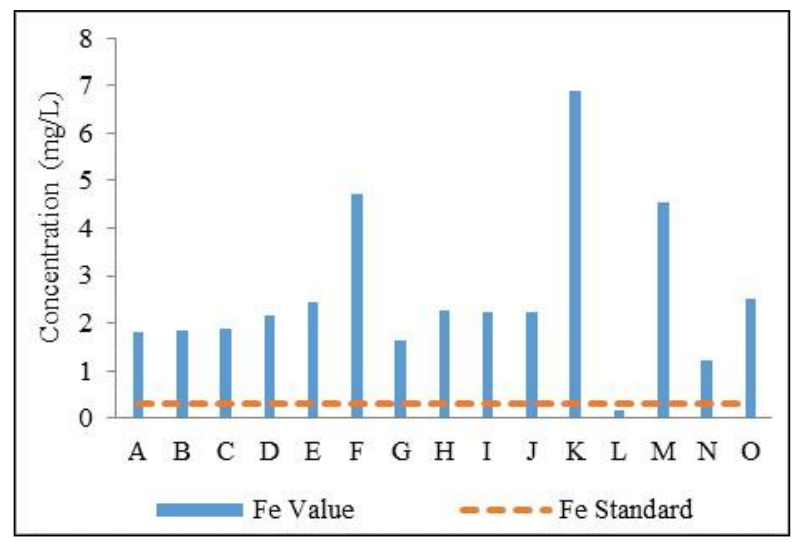

Fig 6. Fe value of groundwater

Heavy metals are naturally present in trace amounts in groundwater. The concentration of heavy metals in groundwater depends on the soil properties, the type of rock that the groundwater passes through and the influence of environmental pollution around the groundwater source. High concentration of iron metal will cause groundwater color will be yellowish, corrosion of metal objects, deposition of water pipe walls and accelerate the growth of Fe bacteria in groundwater (Rahadi, B., Lusiana, N., 2012).

\subsection{Lead}

Lead content in groundwater in range $0,0026 \mathrm{mg} / \mathrm{L}-$ $0,1316 \mathrm{mg} / \mathrm{L}$ and average $0,022 \mathrm{mg} / \mathrm{L}$. Lead standard permitted by Health Minister Regulation is $0,01 \mathrm{mg} / \mathrm{L}$. 6 groundwater $(40 \%)$ have $\mathrm{Pb}$ value above the drinking water quality standard while the others still have $\mathrm{Pb}$ metal content below the quality standard (Fig.7). This must be a concern because $\mathrm{Pb}$ can accumulate and pollute groundwater.

The heavy metal content cannot be removed and it is toxic and carcinogenic. In humans, heavy metal can disrupt health depend on the part which are exposed of heavy metals. Heavy metal can cause cancer, allergies and at high dose can cause death (Yandra, A.P., Mairizki. F., 2020). 


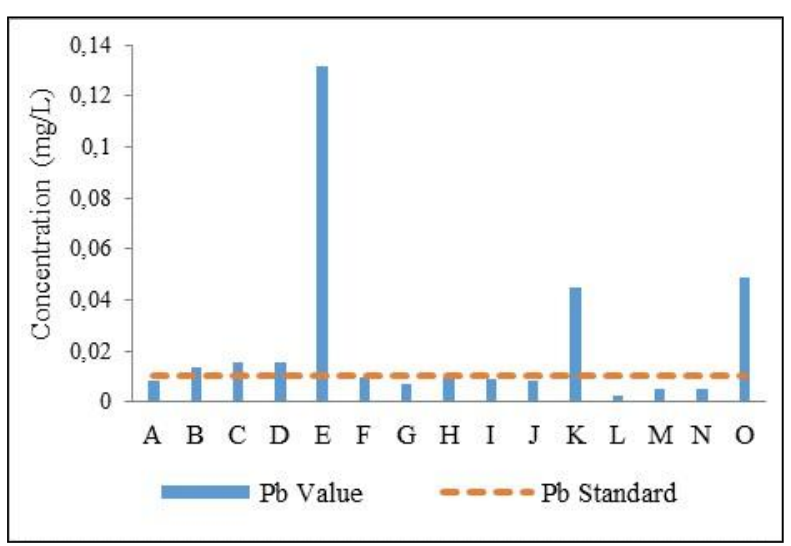

Fig 7. Pb Value of Groundwater

\section{Conclussion}

Groundwater samples were taken from dug wells in Teluk Nilap area, Rokan Hilir, Riau. All groundwater meet the requirements for drinking water quality according to the Health Minister Regulation No.492/MENKES/PER/IV/2010 in terms of physical parameters with temperature average $30^{\circ} \mathrm{C}$ and TDS average $312,5 \mathrm{mg} / \mathrm{L}$. However, almost all groundwater does not meet the drinking water quality requirements based on its chemical parameters. All groundwater are acidic with $\mathrm{pH}$ average 5,6, containing sulfate and nitrate with average value $48,8 \mathrm{mg} / \mathrm{L}$ and $11,86 \mathrm{mg} / \mathrm{L}$, respectively. Groundwater water also have iron and lead metal above the permitted standard with average value $2,57 \mathrm{mg} / \mathrm{L}$ and $0,022 \mathrm{mg} / \mathrm{L}$. Therefore, groundwater in research is not recommended as drinking water.

\section{Acknowledgements}

The authors would like to give an acknowledgment to Universitas Islam Riau and the Ministry of Education and Culture for providing research fund. Additional thank you for all students that help authors to collect data at field.

\section{References}

Annapoorna, H., Janardhana, M.R. 2015. Assessment of Groundwater Quality for Drinking Purpose in Rural Areas Surrounding a Defunct Copper Mine. Aquatic Procedia 4, 685-692. https://doi.org/10.1016/j.aqpro.2015.02.088.

Firdaus, A.R., Paenrongi, A.V., Safira, B., Pertiwi, D.A., Aqsha, E.S., Beloratte, J., Asadullah, M., Syilvana, P.P. 2017. Analisis Kualitas Airtanah Berdasarkan Parameter Kekeruhan, TDS (Total Dissolved Solid), pH, dan Zat Organik di Wilayah Bukit Batu Putih, Samarinda, Kalimantan Timur. Jurnal Teknologi Mineral, 5(2), 1-4.

Ibrahim, M.N. 2019. Assessing Groundwater Quality for Drinking Purpose in Jordan : Application of Water Quality Index. Journal of Ecological Engineering, $20(3)$,

101-11. https://doi.org/10.12911/22998993/99740.

Khan A., Khan M.A. 2018. Groundwater Assessment for Drinking Purpose in Gulistan-e-Johar Town, Karachi, Pakistan. Journal of Geoscience, Engineering, Environment, and Technology, 3(4), 200-207. doi: 10.24273/jgeet.2018.3.4.2086.

Lalitha, B.V., Teja, V.S., Rajesh, V. 2016. A study on Assessment of Groundwater Quality and Its
Suitability for Drinking in Shivajipalem Area Visakhapatnam, A.P. International Journal of Engineering Development and Research, 4(2), 6181621.

Mairizki, F., Cahyaningsih, C. 2016. Groundwater Quality Analysis in The Coastal of Bengkalis City Using Geochemistry Approach. International Journal of Engineering and High-End Technology, 1(2), 82-87.

Mutianto, H. 2010. Studi Kualitas Airtanah Untuk Pengembangan di Kawasan Parangtritis, Bantul, Daerah Istimewa Yogyakarta. Jurnal Geografi Gea, 10(2). https://doi.org.10.17509/gea.v10i2.1075.

Naslilmuna, M., Muryani, C., Santoso, S. 2018. Analisis Kualitas Air Tanah dan Pola Konsumsi Masyarakat Sekitar Industri Kertas PT Jaya Kertas Kecamatan Kertosono Kabupaten Nganjuk. Jurnal GeoEco, 4(1), 51-58. https://doi.org/10.20961.ge.v4i1. 19176.

Putra, A.Y., Mairizki, F. 2020. Analisis Logam Berat pada Air Tanah di Kecamatan Kubu Babussalam, Rokan Hilir, Riau. Jurnal Katalisator, 5(1), 47-53. http://doi.org/10.22216/jk.v5i1.5277.

Putra, A.Y., Mairizki, F. 2019. Analisis Warna, Derajat Keasaman dan Kadar Logam Besi Air Tanah di Kecamatan Kubu Babussalam, Rokan Hilir, Riau. Jurnal Katalisator, 4(1), 9-14. http://doi.org/10.22216/jk.v4i1.4024.

Putra, D.B.E., Yuskar, Y., Kausarian, H., Yaacob, W,Z., Hadian, M.S.D. 2019. Saltwater Intrusion Zone Mapping on Shallow Groudwater Aquifer in Selat Baru, Bengkalis Island, Indonesia. Journal of Geoscience, Engineering, Environment, and Technology, 4(1), 16-21. doi:10.25299/jgeet.2019.4.1.2672.

Rahadi, B., Lusiana, N. 2012. Penentuan Kualitas Air Tanah Dangkal dan Arah Pengelolaan (Studi Kasus Kabupaten Sumenep). Jurnal Teknologi Pertanian, 13(2), 97-104. Risky, D.P., Artini, N.P.R., Aryasa, I.W.T. 2017. Penelitian Pendahuluan Kualitas Air Tanah di Banjar suwung Batan Kendal, Kelurahan Sesetan, Kota Denpasar. Medicamento, 3(1), 39-43.

Sasongko, E.B., Widyastuti, E., Priyono, R,E. 2014. Kajian Kualitas Air dan Penggunaan Sumur Gali Oleh Masyarakat di Sekitar Sungai Kaliyasa Kabupaten Cilacap. Jurnal Ilmu Lingkungan, 12(2), 72-82. doi:10.14710/jil.12.2.72-82.

Satrio, Pujiindiyati, E.R. 2017. Karakteristik Air Tanah Akuifer Dalam Sekitar Tempat Pembuangan Sampah Terpadu (TPST) Bantar Gebang-Bekasi, Jawa Barat. Jurnal Teknologi Lingkungan, 18(1), 96-103. https://doi.org/10.29122/jtl.vl8il.48.

Siringoringo, L.P., Rizki R., Nababan J. 2019. Hydrogeochemical and Groundwater Assessment for Drinking Purpose at ITERA Campus Area and Its Surroundings. Journal of Geoscience, Engineering, Environment, and Technology, 4(1), 40-48. doi:10.25299/jgeet.2019.4.1.2478.

Sudaryanto, Suherman, D. 2008. Degradadi Kualitas Airtanah Berdasarkan Kandungan Nitrat di Cekungan Airtanah Jakarta. Jurnal Geologi dan $\begin{array}{llll}\text { Pertambangan, } & 18 & (2), & 61-\end{array}$ doi:10.14203/risetgeotam2008.v18.17.

(C) 2020 Journal of Geoscience, Engineering, Environment and Technology. All rights reserved. This is an open access article distributed under the terms of the CC BY-SA License (http://creativecommons.org/licenses/by$\mathrm{sa} / 4.0 /$ ). 